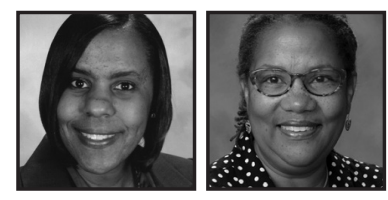

\title{
Bridges for Academic Success: Opening Spaces for Culturally Responsive Practice in an Urban Pre-School
}

\author{
Denise Jones and Susan Browne
}

\begin{abstract}
It has become widely understood that formal early childhood education can be an important factor in school success. Equally significant is the role of culture as a determinant in negotiating school. Thereby, the inclusion of student culture remains an important aspect in conversations on school success. This discourse is capable of promoting learning using the lives of students by building on what they already know, while offering opportunities for academic achievement. This study investigated how professional development workshops on culturally responsive practice for urban pre-school teachers encouraged the examination of current classroom practices and offered a process for transformation.
\end{abstract}

\footnotetext{
thas become widely understood that formal early childhood education can be an important factor in a child's future success. It is during these years that major portions of a young child's intellect, social skills, and personality are developed,
} giving pre-school the opportunity to have significant impact on these areas. However, too often there is a tendency for schools and school curriculum to delegitimize the reallife experiences of culturally diverse students. In fact, for these students, culture has persistently been linked to a lack of school success in troubling ways. Darling-Hammond (2007) points to the standardized test scores of low performing students as a means of further inscribing failure for many students of color. For instance, low performing schools are responsible for making yearly progress despite being underfunded while serving needier students. Although standardized test scores have increased for African American students, on average African American students still do not perform as well as their white counterparts. 
The deeply rooted and pervasive challenges of schools in urban settings continue to be an area of critical concern. These schools have fewer resources and overwhelmingly provide educational experiences inferior to schools with greater resources that lead to a severe opportunity gap and what Ladson-Billings (2006) refers to as an educational debt that is owed. The academic needs of students often appear prior to enrollment in first grade. The Early Childhood Longitudinal Survey of Kindergarten (NCES, 2007) monitored a sample of young students from different ethnic and socioeconomic backgrounds and provided a sample of their early school experiences, and results of their school readiness testing. The results of the study demonstrated that enrolling lowincome children in early childhood programs improves outcomes in elementary school, with benefits that include higher achievement test scores, reduced need for special education services, and lower grade retention rates (NCES, 2007). Research by Grissmer and Eiseman (2008) focusing on the importance of early childhood experiences supports that achievement disparities emerge before students enter the first grade. Georgia, the first state to offer universal pre-kindergarten, authorized a longitudinal study in 1996 that included 3,042 children in Pre-Kindergarten. The result of the study concluded that students who attended Pre-K did better than students who had not attended. Low socioeconomic students who attended early childhood programs performed better throughout school than those students who had not attended early childhood programs. Given this knowledge, Dunne (2010) asserts that the main goal for providing quality early childhood programs is to help eliminate the achievement gap between low socioeconomic status students and their more affluent peers.

\section{Culture as a Critical Determinant in the Ability to Negotiate School}

Classroom environment and the inclusion of student culture are important pieces in conversations on school success. Shevalier and McKenzie (2012) argue that cultural and linguistic diversity are valuable resources in urban schools. They go on to say that teachers who combine culturally responsive teaching with caring, ethics-based approaches are more successful in educating urban students. The National Association for the Education of Young Children (NAEYC) in their 2009 Quality Benchmark for Cultural Competence Project report that for the "optimal development and learning of all children, educators must accept the legitimacy of children's home language, respect the home culture, and promote and encourage the active involvement and support of all families, including extended and nontraditional family units" (p. 2). The report frames home culture as 
family socioeconomic status, family composition, parent's level of educational attainment, abilities of children and family members, family's immigration status, family's religion, family's home and preferred languages, parent's sexual orientation, and the way that a family classifies its race and ethnicity. (pp. 2-3)

Researchers, such as Banks (1999), Gay (2000, 2002), Hale-Benson (1982), Hollins (1993), Nieto (1999), King (1992), and Ladson-Billings (1995, 2006, 2009), have long asserted that student achievement would increase if classroom instruction included students' home cultures. This body of research offers a knowledge base that reminds us that culture is a critical determinant in the ability to negotiate school.

\section{Purpose}

Based on data provided by the National Center for Education Statistics, among the issues that continue to impact urban classrooms are racial, ethnic, and/or class disparities between students and their teachers (NCES, 2010). The 2008 Civil Rights Project reports that as student diversity continues to rapidly grow, the racial composition of teachers remains overwhelmingly white with inadequate attention to helping teachers prepare for the increasing racial transformation in the nation's schools.

The purpose of this study was to investigate how professional development workshops on culturally responsive practice provided for four urban pre-school teachers might encourage the examination of current classroom practices and offer opportunities for transformation where needed. As educators and researchers who share backgrounds and teaching experiences rooted in urban settings, the authors' practice and scholarship are informed by the view that culturally responsive pedagogy works to construct learning in ways that value what students inherently bring with them to school. We contend that culturally responsive practice is capable of offering a bridge that leads to academic success for students in underserved contexts. Yet, Sleeter (2012) points to a gap in research regarding professional development on culturally responsive practice and its impact on student achievement. Nonetheless, according to Phillips, McNaughton, and MacDonald (2004), there remains promise in the ways that professional development has had major influences on adult learners and how teachers instruct students. 


\section{A Culturally Responsive Teaching Stance}

Villegas (2002) describes effective culturally responsive teachers as educators who believe that they are responsible for and capable of bringing about educational change. These teachers know the ways in which students construct knowledge. This kind of teaching is capable of promoting learning, using the lives of students by building on what they already know, while stretching them beyond the familiar. We define "culturally responsive pedagogy" as centering teaching on the students' culture and environment while infusing the district's curriculum. As classrooms become more diverse, so must the practices of teachers. The course of action for restructuring teaching practices to include an emphasis on culture can be achieved through filtering or restructuring the current process. Ladson-Billings (2009) describes the filtering process as incorporating these five characteristics into teaching practice:

1. When students are treated as competent they are likely to demonstrate competence.

2. When teachers provide instructional "scaffolding" students can move from what they know to what they need to know.

3. The focus of the classroom must be instructional where students and teachers engage in serious work that is communicated clearly.

4. Real education is about extending students' thinking abilities.

5. Effective teaching involves in-depth knowledge of both the students and the subject matter. (p. 133)

Similarly, Gay (2002) describes culturally responsive teaching as using the cultural characteristics, experiences, and perspectives of diverse students as a means for adequately teaching them. According to Gay (2000), culturally responsive teaching is illustrated utilizing the following six approaches: 1. Validation (using student learning styles while focusing on the strengths of each student); 2. Comprehensive (teaching to the entire student, that includes social, emotional, cognitive, and content considerations); 3. Multidimensional (focusing on instructional content, learning context, classroom environment, student-teacher relationships, instructional strategies, and student performance); 4. Empowerment (encouraging and motivating students to believe in their own success); 5 . Transformative (using and respecting students' cultural background/experiences and incorporating into instruction; and 6. Emancipatory (guiding students into understanding that there are many definitions of "truth" and all are imperfect). 


\section{Methodology}

This study utilized naturalistic participatory research and raw data were obtained through methods of observation as well as qualitative interviewing (Rubin \& Rubin, 2005). In addition, the participatory approach can be described as a cultural building process (Cochran-Smith \& Lytle, 2009). The study was conducted in a preschool located in a northeastern urban school district. The preschool's mission focuses on a school facility that services the social, emotional, and scholastic needs of students. The 456 students are 91\% African American, 8\% Hispanic, and 1\% other. The school, a new "state of the art" facility, has a staff that is 76\% African American, 20\% Hispanic, and $4 \%$ Caucasian. The mission of the school is to provide students with various learning opportunities with the assistance of personnel, learning resources, as well as resources to prepare for future academic challenges. The school emphasizes utilizing cultural sensitivity in the classroom, however, the sensitivity and importance of incorporating students' real-life experiences and cultural knowledge is not consistently present. The case study approach was used to investigate how professional development on culturally responsive practice impacted the four teachers. Data were analyzed descriptively and underwent Yin's (2003) process of pattern-matching.

\section{Participant Profiles}

The four participants entered the study with prior teaching experience in an urban school district. Three of the four teachers possess master's degrees in education and P-3 certification with the exception of the Kindergarten teacher who has a Bachelor's degree and K-8 certification. The race of the participants included two Caucasian teachers and two African American teachers. The participants were all female and their socioeconomic status was middle class. Participants were selected with less than three years of service at the school. These teachers may not have been fully inculcated into the culture of the school and were more likely to implement change. 
Table 1

Participants' Characteristics

\begin{tabular}{|l|l|l|l|l|}
\hline PARTICIPANTS & MS. KELLY & MS. BENSON & MS. DUNCAN & MS. BENET \\
\hline Education & B.A & M.S./M.Ed. & M.S/M.Ed. & M.Ed. \\
\hline Age & $45-55$ & $45-55$ & $26-30$ & $29-36$ \\
\hline Race & Caucasian & Caucasian & $\begin{array}{l}\text { African } \\
\text { American }\end{array}$ & $\begin{array}{l}\text { African } \\
\text { American }\end{array}$ \\
\hline $\begin{array}{l}\text { Licensure/ } \\
\text { Certification }\end{array}$ & K-8 & K-8 & P-3 Cert. & P-3 Cert. \\
\hline $\begin{array}{l}\text { Years at } \\
\text { school }\end{array}$ & 2 & 1 & 2 & 2 \\
\hline $\begin{array}{l}\text { Grade } \\
\text { Resident and } \\
\text { teaching in } \\
\text { same city }\end{array}$ & $\mathrm{K}$ & Pre-K & Pre-K & Pre-K \\
\hline
\end{tabular}

Below are the responses to the survey question that asked participants to "Describe their knowledge/beliefs around teaching African American students in urban settings."

\section{Ms. Kelly}

Ms. Kelly explained that she adjusts her pedagogy according to the needs of her students. She said if real learning takes place it is because the educators are able to relate to their students. Ms. Kelly described herself as an educator who believes that sensitivity towards social class takes precedence over culture when comparing urban and suburban students. Ms. Kelly strives to integrate her students' culture through various activities such as celebrations, classroom assignments, and books.

\section{Ms. Benson}

Ms. Benson described her prior knowledge of teaching urban students as minimal. She believes that while teachers learn about their students, the students in return learn about their teacher. She described her pedagogy as a multifaceted one that considers various issues of her students such as working single mothers and fathers, siblings raising siblings, hunger, and bullying. She values parents as well as her relationship with her students and stated that her students trusting and feeling safe within her classroom was also an important part of her pedagogy. 


\section{Ms. Duncan}

Ms. Duncan began teaching in an urban school district through Teach for America. Her teaching beliefs focus on success for all students regardless of race or socioeconomic status. Her philosophy of teaching realizes that there must be considerations of social class, poverty, and high unemployment, especially in the city where her students live. Her pedagogy has a lens that views student and parent.

\section{Ms. Benet}

Ms. Benet has primarily taught Hispanic students in urban districts. She believes that effective classroom structure builds a strong foundation of consistency for students.

The table below is a summary of responses to an interview question that asked the participants to specifically address how they draw on their students' culture when teaching.

\section{Table 2}

\section{Teachers' Initial Responses}

\begin{tabular}{|c|c|c|c|c|}
\hline & MS. KELLY & MS. BENSON & MS. DUNCAN & MS. BENET \\
\hline $\begin{array}{l}\text { How do you } \\
\text { draw upon } \\
\text { students' } \\
\text { culture/ } \\
\text { experiences } \\
\text { in the } \\
\text { classroom? }\end{array}$ & $\begin{array}{l}\text { In my classroom } \\
\text { I display and } \\
\text { read books } \\
\text { that relate to } \\
\text { my children's } \\
\text { culture. }\end{array}$ & $\begin{array}{l}\text { We turned a } \\
\text { fake spruce tree } \\
\text { where the kids } \\
\text { learned about } \\
\text { evergreens and } \\
\text { needles into a } \\
\text { family tree with } \\
\text { pictures of their } \\
\text { families and } \\
\text { they were proud } \\
\text { to stand up and } \\
\text { identify their } \\
\text { family members. }\end{array}$ & $\begin{array}{l}\text { We use Spanish } \\
\text { music, Latin } \\
\text { dance songs, } \\
\text { and language. }\end{array}$ & $\begin{array}{l}\text { I find that I } \\
\text { need to make a } \\
\text { conscious effort } \\
\text { to incorporate } \\
\text { other cultures } \\
\text { in my teaching } \\
\text { methods. }\end{array}$ \\
\hline
\end{tabular}


These initial responses indicate that each of the teachers recognize the role of culture in a pedagogical stance. Although the participants embraced the role of culture in teaching, in large part, the discussion did not move beyond superficial understandings or engage in discourse that emerged from theoretical perspectives on culturally responsive practice. Creating a safe space for participants to discuss their pedagogical perspectives was an integral part in assisting with opportunities for transformation. Most of the teachers initially believed that the role of culturally centered practice was primarily accomplished through the use of art, music, experimenting with food, and celebrating holidays. Banks (1999) describes the teachers' initial beliefs as lower level generalizations. References to families and economic status offered a strong bridge for building a deeper knowledge base.

\section{Professional Development Workshops}

The professional development workshops were constructed based on the ways participants expressed their understandings of culturally responsive practice. They were designed to offer opportunities to embrace a pedagogy that Gay (2002) would describe as comprehensive, multidimensional, empowering, and/or transformative.

\section{Professional Development Workshop 1}

Responding to multicultural picture books to discuss diversity in families. The workshop began with a conversation in response to three picture books, Visiting Day by Jacqueline Woodson, A Shelter in Our Car by Monica Gunning, and Heather Has Two Mommies by Leslea Newman. The workshop focused on how the books represent a changing definition of family.

\section{Professional Development Workshop 2}

Cultural autobiographies and envisioning culturally responsive practice. Participants were asked to write their own cultural autobiography that included life events related to education, family, religious tradition, victories, as well as defeats. The intent of this assignment was to help the participants build and document personal beliefs so that they could connect how these events formed their traditions and cultural beliefs (Banks, 1994). The assignment described Banks' philosophy that writing your own autobiography helps identify beliefs and attitudes that form the traditions and 
values of culture. Gay's (2000) theory of responsive teaching was also introduced to help participants further consider fostering culturally responsive pedagogy.

\section{Professional Development Workshop 3}

Culturally situated practice as a journey. Each meeting began with a discussion of Professional Standards for Teachers and how they connected to the planned goals of the workshop. This workshop focused on the journey of cultural responsiveness in education. We wanted the participants to gain a sense of understanding that change, particularly reforming one's pedagogy, is a process, much like a journey. The participants returned with their autobiographies and we asked that they listen to them for the characteristics that may have shaped the teacher's cultural background particularly as it related to Gay's theory on culturally responsiveness.

\section{Professional Development Workshop 4}

Crafting a cultural biography of a student. This workshop focused on identifying a student of a different culture/background and then writing a biography. The assignment then asked participants to do a cross-analysis of teacher and student by utilizing the participant's autobiography and a student's biography. The intended result was that participants learn how to form a deeper understanding of their students. The concept was reinforced that in order for teachers to effectively teach their students, they had to first "know" their students.

The second part of the workshop focused on creating a culturally responsive classroom using Gays' (2002) concept of multidimensional techniques to foster culturally responsive teaching.

\section{Professional Development Workshop 5}

Culturally responsive teaching through classroom management. This workshop focused on practicing culturally responsive practice through classroom management. A culturally responsive classroom includes pedagogical approaches that guide the management decisions that teachers make. Weinstein, Curran, and Tomlinson-Clarke (2003) suggested that culturally responsive classroom management is an extension of culturally responsive teaching, which utilizes the background of a student's social experiences. Honoring culture was illustrated through the five essential elements of culturally responsive classroom management that include: 1. recognizing of one's own cultural lens, and biases (Weinstein et al., 2003); 2. acknowledging students' cultural 
backgrounds such as learning styles and behavior (Sheets \& Gay, 1996); 3. establishing awareness of the broader, social, economic, and political context of school policies and practices and how they might marginalize students (Black, 2006); 4. using culturally appropriate management strategies to foster diversity (Weinstein et al., 2003); and 5. committing to creating a caring community by establishing positive relationships between teacher and student (Weinstein et al., 2003).

\section{Professional Development Workshop 6}

Investigating practices and transforming pedagogy. The final workshop focused on supporting classroom change that participants made over the course of the workshops. The change model was an important element for reinforcing ideas and strategies introduced over the course of the study. Considerable time was devoted to discussing the following six-step change model (Beer, Eisenstat, \& Spector, 1990):

1. Diagnosing the current situation-Does your current pedagogy address the needs of your students?

2. Developing a vision for change-Do you change your philosophy when the current classroom strategy is unsuccessful?

3. Gaining commitment to the vision-Do you have support in place to help you?

4. Developing an action plan-Do you utilize a set of steps to help establish change within the classroom during a certain timeframe?

5. Implementing change-Do you utilize tools or strategies to help foster culturally responsive teaching?

6. Assessing and reinforcing change-Do you utilize strategies to help reinforce the success of your pedagogy?

\section{Findings}

Collectively, the participants remained vigilant about the importance of their students excelling academically. To varying degrees, participants recognized that they excluded culture from teaching practices while focusing more on concepts or subject 
matter. In addition, participants believed because of their students' age and grade level, an emphasis on culture was not appropriate or necessary.

It was through professional development workshops and reflective practice that the participants began to consider responsive practice as a pedagogical stance. As a result of the workshops, they were becoming mindful of how traditional teaching practices, combined with district policy and mandated state standards, often excluded student culture. This mindfulness was significant to the potential instantiation of practice that uses culture to inform instruction.

The participants were asked to investigate their instructional practices and their evolving transformation. The table below demonstrates participants' responses on change relevant to fostering culturally responsive pedagogy.

Table 3

\section{Supporting Change}

\begin{tabular}{|l|l|l|l|l|}
\hline $\begin{array}{l}\text { Current } \\
\text { pedagogy } \\
\text { addresses the } \\
\text { needs of all } \\
\text { students }\end{array}$ & Always & Always & Sometimes & Always \\
\hline $\begin{array}{l}\text { Philosophy of } \\
\text { change }\end{array}$ & Always & Always & Always & Always \\
\hline $\begin{array}{l}\text { Current } \\
\text { classroom } \\
\text { support }\end{array}$ & Sometimes & Sometimes & & Sometimes \\
\hline $\begin{array}{l}\text { Available } \\
\text { tools for } \\
\text { fostering } \\
\text { culturally } \\
\text { responsive } \\
\text { pedagogy }\end{array}$ & Sometimes & Always & Sometimes & Always \\
\hline $\begin{array}{l}\text { Present } \\
\text { positive } \\
\text { reinforcement } \\
\text { strategies }\end{array}$ & Always & Always & Sometimes & Always \\
\hline
\end{tabular}


The teachers began to generously examine their own lens for understanding culturally responsive pedagogy. They acknowledged that change was necessary, as well as accompanying support. The six-step change model of Beer et al. (1990) helped facilitate the participants shift from "I know what culturally responsive pedagogy is" to "I don't know as much as I thought but will make changes to implement the practice."

As the preliminary findings emerged, a limited knowledge of culturally responsive pedagogy was evident. An analysis of the data indicated that each participant demonstrated a cursory reflective nature regarding the role of a culture in classroom practice. Thereby, all of the teachers fell short of demonstrating a strong pedagogical understanding around the transformative potential of culturally responsive practices. Gay (2000) describes "transformative pedagogy" as using students' cultural background as a means of establishing instructional lessons. Moreover, Gay asserts that teachers have to first become aware of their instructional methods and then how to modify them to adapt to diverse student populations. The participants, according to Argyris and Schon (1974), demonstrated incongruities between their espoused theories and theories in use. An analysis of data through the lens of culturally relevant theory positioned all the teachers as emerging with the utilization of culturally responsive pedagogy as an empowerment process.

Creating the workshops as a safe space for participants to discuss their pedagogical perspectives was an integral part of embracing culturally responsive practices as transformative pedagogy.

\section{Evolving Perspectives}

Early in the study Ms. Kelly explained,

Truthfully I don't think I'm right for this study. I just don't get it; I don't get culturally responsive teaching. When I was going to school to become a teacher I was taught to just teach subject matter and nothing else.

The professional development workshops were intended to support teachers' pedagogical stance, rather than fix perspective and theory (Hawley \& Nieto, 2010). The workshops were a significant place from which each teacher's perspective could evolve. 
Ms. Kelly: "I will make more of an effort to bring my students' culture into all content areas and I would like to make my class more multicultural while exposing children to other cultures in different subject areas."

Ms. Duncan: "I will do my best to be more responsive to the needs of all students in my class, whether they come from a different cultural background than me. In addition, I will continue speaking with other professionals who may be more familiar with the culture than I am, so I can incorporate as much of their cultures and belief systems within the classroom."

Mrs. Benet: "I understand a little bit more why it is important and how I can improve my practices. I will use the knowledge gained from the workshops to guide my planning and as a reminder to consider the beliefs and culture of my students, their families, and the learning community."

Mrs. Benson: "The workshops have brought more ideas to embed into my lessons. I know I can be creative enough to allow more sharing of students' lives in the classroom."

The teacher perspectives illustrated a strong belief in demonstrating fairness to students, eliminating prior biases, establishing a positive classroom environment, being sensitive to each student's religious beliefs, and eliciting instructional materials suited for the diversity of the students. While the participants' perspectives were directly linked to their espoused theory, they all emphasized the importance of including their students' culture into their instructional lessons as a pedagogical stance.

Each participant arrived at different times regarding her own consciousness of fostering culturally responsive pedagogy and taking a stance to integrate students' culture into the curriculum. The study introduced several purposeful research questions that examined each teacher's beliefs, values, understanding, and implementation of culturally responsive pedagogy in their classrooms. The intent was to explore each teacher's current pedagogy and how it facilitated learning of culturally diverse students. The larger goal of the study was to ensure that the students' culture was being implemented within the curriculum and during instructional class time through the use of professional development workshops. The analysis of the data demonstrated that while the teachers believed they were knowledgeable about the preschool environment, they needed to gain knowledge of their students to help build a strong relationship. 
Culturally relevant theory helped to explore the participants' instructional methods and also allowed them to self-evaluate and question their current pedagogy. This type of questioning is similar to unloading and reloading a large box of books. The teachers initially rejected that their previous knowledge was faulty or needed to be "unloaded and then reloaded" with the different information. The participants remained vigilant about the importance of their students excelling academically. The teachers, in varying degrees, were mindful of how "traditional teaching" practices, combined with district policy and mandated state standards, tended to exclude student culture from the curriculum. It was through professional development workshops and reflective practice that the participants had become informed of the integration of student culture within their daily lesson.

\section{Conclusion}

Social inequality is evident in policies, teacher preparation programs, and public schools where culture is vaguely mentioned. Teachers should be interested in linking the home environment to classroom practices so that student-teacher interactions are meaningful as well as significantly impacting student success. The teachers, as a result of this study, have made definitive strides in cultural references and continue to explore fostering culturally responsive pedagogy within their classroom practices. This exploration of culturally responsive pedagogy is critical for all teachers who differ culturally from their students but understand that it is necessary for the rights and academic growth of the students.

Ongoing professional development on implementing culturally responsive teaching in urban schools, particularly in an early childhood setting, is a significant course of action to support school reform. This structure supports apprenticing students as members of a learning community where knowledge is contextualized and students' real-life experiences are legitimized (Ladson-Billings, 2009) and it works against conceptions that African American cultural knowledge serves as an impediment to educational achievement (Gadsden, 1994). The participants in this study agreed that their initial knowledge of culturally responsive pedagogy was limited and that further work regarding integrating their students' culture needed discussion. The teachers began to examine their own lens for understanding culturally responsive pedagogy. Culturally relevant theory helped the participants to self-evaluate and question their current pedagogy. It was through professional development workshops and reflection 
on practice that the participants became informed about the integration of student culture in the classroom.

Professional development that is geared towards understanding culturally responsive teaching can engender significant shifts in classroom practice. It can help impact classroom climate and student learning. Such workshops can provide a knowledge base that was not embedded in teacher education programs. The development of culturally responsive teachers helps establish a foundation for strong classroom environments that meet the needs of students while holding promise for increasing student achievement.

\section{References}

Argyris, C., \& Schon, D. (1974). Theory in practice: Increasing professional effectiveness. San Francisco: Jossey-Bass Publishers.

Banks, J. (1994). Multiethnic education: Theory \& practice. Boston: Allyn \& Bacon.

Banks, J. (1997). Teaching strategies for ethnic studies. Needham Heights, MA: Allyn \& Bacon.

Banks, J. (1999). An introduction to multicultural education. Needham, MA: Allyn \& Bacon.

Beer, M., Eisenstat, R., \& Spector, B. (1990). The critical path to corporate renewal. Boston: Harvard Business School Press.

Black, S. (2006). Respecting differences: Diverse learners can blossom in culturally responsive classrooms. American School Board Journal, 193(1). Retrieved from http://www.asbj.com.

Cochran-Smith, M., \& Lytle, S. (2009). Inquiry as stance: Practitioner research for the next generation. Teachers College Press: Columbia University.

Darling-Hammond, L. (2007). Race, inequality and educational accountability: the irony of 'No Child Left Behind'. Race, Ethnicity and Education, 10(3), 245-260. doi:10.1080/ 13613320701503207.
Dunne, D. (2010). Early childhood teachers: Do qualifications matter? Retrieved from http:// family.go.com/education/article-199461 -early-childhood.

Gadsden, V. (1994). Literacy, identity and education among African Americans: The communal nature of learning. In Mwalimu J. Shujaa. (Ed.). Too much schooling too little education: A paradox of black life in white societies. Trenton, NJ: Africa World Press.

Gay, G. (2000). Culturally responsive teaching: Theory, research, and practice. New York: Teachers College Press.

Gay, G. (2002). Preparing for culturally responsive teaching. Journal of Teacher Education, 53(2), 106-116. doi:10.1177/0022487102053002003.

Grissmer, D.W., \& Eiseman, E. (2008). “Can Gaps in the Quality of Early Environments and Noncognitive Skills Help Explain Persisting Black-White Achievement Gaps?" In Steady Gains and Stalled Progress: Inequality and the Black-White Test Score Gap, edited by K.A. Magnuson and J. Waldfogel (pp. 139180). New York: Russell Sage Foundation. 
Hale-Benson, J. (1982). School related factors and teacher behavior that contribute to low self-image in students. In S. Denbo \& L. Beaulieu. (Eds.), Improving Black Student Achievement. Retrieved from http://www. maec.org/achieve/2.html

Hawley, W., \& Nieto, S. (2010). Closing opportunity gaps. $A S C D, 66(3), 66-71$. Retrieved from http://www.ascd.org.

Hollins, E. (1993). Assessing teacher competence for diverse populations. Theory Into Practice, 32(2), 93-99. Retrieved from http://jstor.org/ stable.

King, J. E. (1992). Diaspora literacy and consciousness in the struggle against miseducation in the Black community. Journal of Negro Education, 61(3), 317-340. Retrieved from http://www.jstor.org/stable/2295251

Ladson-Billings, G. (1995). But that's just good teaching!: The case for culturally relevant Pedagogy. Theory Into Practice, 34(3), 159165. Retrieved from http://www.jstor.org/ stable/1476635.

Ladson-Billings, G. (2006). From the achievement gap to the educational debt: Understanding achievement in U.S. school. Educational Researcher, 35(7), 3-12.

Ladson-Billings, G. (2009). The dream keepers: Successful teachers of African American Children. San Francisco: Jossey-Bass.

National Association for the Education of Young Children (NAEYC). (2009). Quality Benchmark for Cultural Competence Project Report. Retrieved from www.naeyc.org/files/naeyc/ file/policy/state/QBCC_Tool.pdf

National Center for Education Statistics (NCES), U.S. Government Printing Office. (2007). Early childhood longitudinal survey of kindergarten. Retrieved from http://nces.ed.gov.
National Center for Education Statistics (NCES), U.S. Government Printing Office. (2010). Educational achievement and Black-White inequality. Retrieved from http://nces.ed.gov.

Nieto, S. (1999). The light in their eyes: Creating multicultural learning communities. New York: Teachers College Press.

Phillips, G., McNaughton, S., \& MacDonald, S. (2004). Managing the mismatch: Enhancing early literacy progress for children with diverse language and cultural identities in mainstream urban schools in New Zealand. Journal of Educational Psychology, 96, 309-323.

Rubin, H., \& Rubin, I. (2005). Qualitative interviewing: The art of hearing data. Sage Publications. Greenwich, CT.

Shevalier, R., \& McKenzie, B. A. (2012). Culturally responsive teaching as an ethics- and care-based approach to urban education. Urban Education, 47(6), 1086-1105. doi:10.1177/0042085912441483

Sleeter, C. (2012). Confronting the marginalization of culturally responsive pedagogy. Urban Education, 47(3), 564-582. doi:10.1177/0042085911431472.

Villegas, A. M. (2002). Preparing culturally responsive teachers: rethinking the curriculum. Journal of Teacher Education, 53(1), 20-32. doi:10.1177/0022487102053002003

Weinstein, C., Curran, M., \& Tomlinson-Clarke, S. (2003). Culturally responsive classroom management: Awareness into action. Theory Into Practice, 42(4), 269-276. doi:10.1207/s15430421tip4204_2.

Yin, R. (2003). Case study research: Design and methods. Thousand Oaks, CA. 


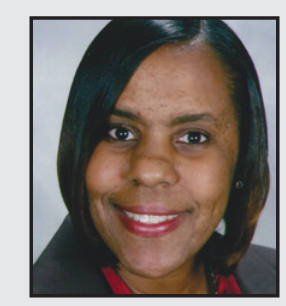

Denise Jones is a visionary leader with 14 years of experience working with diverse student populations in public schools. She earned her doctorate in educational leadership from Rowan University that focused on fostering a culturally sensitive pedagogy with students from low socioeconomic backgrounds. Dr. Jones holds a Principal Certificate of Eligibility from the state of New Jersey and has experience as a classroom teacher, student teacher mentor, professional development chair, curriculum committee representative, and educational consultant. Her research interests are in the areas of school leadership, culturally responsive pedagogy, parent involvement, early childhood education, professional development, and urban education.

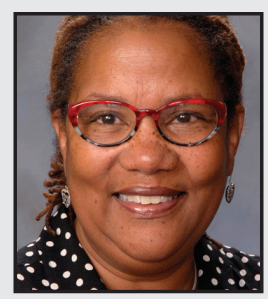

Susan Browne advises the Undergraduate Reading Endorsement Program at Rowan University where she teaches undergraduate and graduate literacy courses and serves as a research advisor to Masters and doctoral candidates. Formerly a School District of Philadelphia classroom teacher, she is a teacher consultant for the Philadelphia Writing Project, coordinator of the Children of the Sun Literary Club at Bushfire Theatre of Performing Arts, and consultant for Literacy Empowerment and Enrichment Partnership (LEEP). In the city of Camden, she currently works with pre-school teachers in the area of early literacy at the Center for Family Services through a universitybased partnership. 